\title{
Nye kurs og læremidler om vurdering av selvmordsrisiko
}

\author{
Ved Elin Anita Fadum og Henning Herrestad
}

Helsepersonell som skal vurdere selvmordsrisiko, må i følge helsepersonelloven
ha tilstrekkelig kompetanse. Ledelsen har ansvar for at nødvendig opplæring blir gitt.

Seksjon for selvmordsforskning og -forebygging (SSFF) arbeider for å legge til rette for flere læringsressurser til støtte for opplæring i selvmordsrisikovurderinger. Her følger en kort presentasjon av tilgjengelige læringsmidler som tilbys ved SSFF.

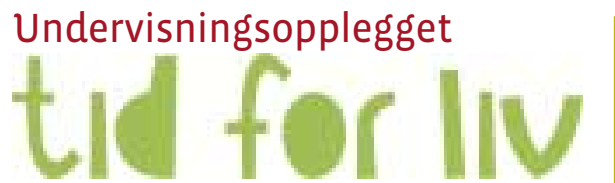

Tid for liv er et komplett undervisningsopplegg som tar for seg sentrale tema og problemstillinger som kan oppstå i møte med pasienter som har gjort villet egenskade. U tgangspunktet for undervisningsopplegget er en undervisningsfilm som er blitt til i et samarbeid mellom selvmordsforskere og behandlere som medvirker i filmen. På DV D-platen finner man i tillegg til undervisningsfilmen flere korte illustrasjoner som eksempler på hvordan vurdering av selvmordfare kan gjøres. Til undervisningsfilmen er det laget et undervisningshefte med korte tekster og refleksjonsoppgaver som er basert på klinikeres erfaringer fra samtale med pasienter som har gjort villet egenskade. Sammen med filmen og undervisningsheftet følger en lærerveiledning med forslag til hvordan undervisningen kan legges opp. SSFF tror at undervisning om risikofaktorer og diagnostikk kombinert med øvingsoppgaver kan hjelpe klinikeren til å utvikle sine kliniske ferdigheter og bli tryggere på hvordan han/hun kan stille spørsmål og kartlegge eventuell selvmordsfare. Vårt mål er at undervisningsmaterialet Tid for liv skal være et praktisk hjelpemiddel i undervisningen av leger, psykologer og andre grupper av behandlere samt medisinstudenter, psykologstudenter og andre studenter. U ndervisningsopplegget sel ges til hel seforetak, undervisningsinstitusjoner, fastleger og annet helsepersonell og kan bestilles fra Seksjon for selvmordsforskning og -forebygging.

\section{Suicidalvurderingsprogrammet, et e-læringsprogram}

På SSFFs nettsider www.sel vmord.no (under menypunktet $U$ tdanning) ligger det gratis og åpent tilgjengelig for alle et el ektronisk læringsprogram om vurdering av risiko for selvmord hos pasienter.
For å kunne bruke det må man ha en PC med bredbåndstil gang til I nternett samt lyd og filmvisningsprogrammet

Q uicktime (som kan lastes ned gratis).

E-læringsprogrammet gir brukeren flere ulike læringsmuligheter. $M$ an får tilgang til en artikkel om vurdering av selvmordsrisiko man kan skrive ut og lese, eller lese på skjerm. $M$ an kan se filmer om tre ulike pasientvurderinger og teste om man selv vurderer deres risiko for selvmord likt med behandleren i hver av filmene. $M$ an kan prøve seg på en test av sine kunnskaper om selvmord, og man kan gå gjennom en læringssti hvor man svarer på spørsmål og får respons på svarene i form av kommentarer, relevante filmklipp og avsnitt fra artikkelen.

Filmene i e-læringsprogrammet viser tre ulike pasientvurderinger som er henlagt til legekontor, psykiatrisk poliklinikk og psykiatrisk døgnavdeling. Pasientene er spilt av profesjonelle skuespillere, mens behandlerne spiller seg selv. Programmet ble utviklet med tanke på undervisningen av medisinstudenter, men vi tror mange andre grupper kan ha et læringsutbytte av å bruke det. Vi er takknemlige om brukerne tar seg tid til å fylle ut et nettskjema med evaluering etter bruken.

SSFF er nå i ferd med å utvikle en ny versjon av e-læringsprogrammet. Vi har filmet tre nye pasientvurderinger, men nå spiller alle behandlerne allmennleger. De har enten rolle som fastlege eller som legevaktslege. M ålgruppen for dette programmet er al Imennleger som ønsker å styrke eller friske opp sine kunnskaper om vurdering av selvmordsrisiko. Brukeren blir utfordret til å være med på vurderingene underveis i pasientsamtalene, til å vel ge tilnærming og til å krysse av for sine observasjoner. $V$ år tanke er å distribuere dette programmet på en DV Dplate slik at man kan se filmene uten å ha Internettforbindelse. Vi regner med å kunne tilby programmet fra 2009.
Kurslederkurs i selvmordsforebygging i psykisk helsevern

De nasjonale retningslinjene for forebygging av selvmord i psykisk helsevern (2008) pålegger hel seforetakene å gi sine ansatte den nødvendige opplæring for å kunne gjøre tilfredsstillende selvmordsrisikovurderinger og gi pasientene forsvarlig behandling i henhold til retningslinjene. SSFF ønsker, i samarbeid med de regionale ressurssentrene om vold, traumer og selvmordsforebygging (RVTS), å støtte helseforetakene $\mathrm{i}$ dette arbei det gjennom å tilby dem kurslederkurs.

Det forutsettes da at helseforetaket utpeker aktuelle kursholdere. Kursholdere bør rekrutteres både for undervisning overfor ansatte med selvstendig behandlingsansvar og overfor ansatte med ansvar for miljøterapi, pleie og observasjon. Kursledere forutsettes å være erfarne medarbeidere som primært trenger å lære det som er nytt med de nasjonal e retningslinjene, og som har påvirkningskraft i forhold til hel seforetakets ansatte. H østen 2008 vil det bli holdt en kursdag i tilknytning til hvert av RV TS-ene ( 0 slo, K ristiansand, Bergen, Trondheim og Tromsø) der man vil gjennomgå kunnskapsstatus på feltet og undervise i hvordan gjøre og dokumentere en selvmordsri sikovurdering. Kurslederne, som komme fra SSFF, vil også gjennomgå kursmateriale deltagerne selv kan bruke når de holder kurs ved sine respektive hel seforetak. SSFF vil også arrangere kurs med spesial temaet Behandling av kronisk suicidale pasienter.

$U \mathrm{t}$ fra tilbakemeldinger fra kursledere om hva de har behov for av opplæring vil vi eventuelt planlegge ytterligere kurslederkurs i 2009.

For en fullstendig oversikt over aktuelle kurs og læremidler, se www.selvmord.no Utdanning - Undervisningssett og filmer 


\section{Verdensdagen for selvmordsforebygging 10. september 2008}

vivat

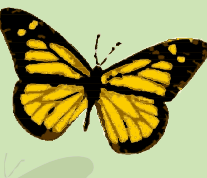

\section{Førstehjelp ved selvmordsfare}

Førstehjelp ved selvmordsfare er et todagers intensivt kurs som retter seg mot alle som i sitt virke kommer i kontakt med selvmordsnære mennesker. Kurset har en praktisk, tverrfaglig tilnærming, der deltakerne lærer å oppfatte faresignaler og intervenere i selvmordskriser. Gjennom rollespill, forelesninger, videofilmer og praktiske øvelser får deltakerne ferdighetstrening og større trygghet i møte med mennesker som kan være i selvmordsrisiko.

På kurset lærer man å:

- Fange opp mennesker som har det vondt og som kan være i selvmordsfare

- Stille direkte spørsmål om selvmordstanker

- Hjelpe personen i selvmordsfare til å snakke om det som er vanskelig

- Gjøre en enkel risikovurdering

- Lage og iverksette en plan med vedkommende hvor målet er å berge livet

- Bruke lokale ressurser i krisehjelp

Undervisningsprogrammet ble opprettet i 2000 som et av flere tiltak under Handlingsplan mot selvmord, og siden den gang har ca. 14000 deltakere gjennomført kurset. Programmet er finansiert av Helsedirektoratet.

Mer informasjon om planlagte kurs finnes på www.unn.no/vivat Interesserte kan også ta kontakt med VIVAT V/Hans Lander på telefon 77627823 eller e-post:vivat@unn.no

Elin A nita Fadum er stipendiat ved Seksjon for selvmordsforskning og -forebygging (SSFF).

$H$ enning $H$ errestad er nestleder og dr.philos. ved SSFF.

\section{Tenk globalt. Planlegg nasjonalt. Handle lokalt.}

$\AA$ rets motto for $V$ erdensdagen uttrykker ønsket om å utvikle en global bevissthet rundt selvmord som en hyppig årsak til for tidlig død. M ottoet setter fokus på de politiske rammene for det sel vmordsforebyggende arbeidet og peker på behovet for at de mange praktiske forebyggingsprogrammene kan omforme politiske uttal el ser og forskningsresultater til aktiviteter på lokalt nivå.

Verdensdagen for selvmordsforebygging er en internasjonal dag som markeres over hele verden. I N orge er LEVE - Landsforeningen for etterlatte ved selvmord - den nasjonale koordinatoren, og LEV E har arrangementer i alle fylker. Verdensdagen for selvmordsforebygging er støttet av Verdens hel seorganisasjon og er et initiativ fra IA SP (International A ssociation for Suicide Prevention).

LEVE er en frivillig organisasjon som arbeider for at etterlatte ved selvmord skal få støtte og omsorg, og for å forebygge selvmord. LEV E har fylkeslag i alle landets fylker, og du finner informasjon om oss på www.leve.no.

LEV E har nettopp fullført sin første treårsperiode som nasjonal koordinator for Verdensdagen, og det gir oss mulighet til å kikke oss over skulderen og se hva som har skjedd i løpet av perioden 2005-2007, hvor LEVE har arbeidet med å etablere V erdensdagen på landsbasis innad i organisasjonen og utad, som en internasjonal dag som flest mulig har hørt om.

Verdensdagen for selvmordsforebygging 10. september ble markert første gang i N orge i 2004 - den gang av Seksjon for selvmordsfors kning og -forebygging. En håndfull fylkeslag fra LEVE var også med og markerte dagen.

I O slo var det en større, nasjonal markering hvor daværende statsminister Kjell M agne Bondevik, holdt en appell. Fra 2005 overtok LEV E koordineringsansvaret og ansatte en prosjektleder i en $50 \%$ stilling. Dette året hadde alle LEV Es fylkeslag en markering. H elsedirektoratet har siden starten bidratt med finanisering, både til nasjonal koordinering og til nasjonale og lokale arrangementer.

Tanken om nasjonale markeringer som henvender seg til forskjellige grupper ved å ha en variasjon i uttrykksformene og som i tillegg har en bred tilgjengelighet, har vært vellykket. I 2005 markerte LEV E Verdensdagen i 0 slo med et arrangement i 0 slo Konserthus. I 2006 inviterte LEV E til en kunstutstilling på Rådhusplassen i 0 slo, som fikk en overveldende respons. U ten dørsutstillingen involverte både skulptur-, installasjons- og billedkunst. U tstillingen ble sett av ca. 800000 mennesker i løpet av de fjorten dager den stod, og samarbei det med kunstnerne gikk knirkefritt. I fjor ble det bestemt at ett fylkeslag skulle stå som arrangør for den nasjonale markeringen. LEVE H ordaland stod for et todelt arrangement i Bergen. 9. september inviterte LEV E til en veldedighetskonsert i G rieghallen med bl.a. M ari Boine, og 10. september var ca. 300 deltakere samlet på den nasjonale fagkonferansen i G rieghallen med temaet Selvmord i alle faser av livet.

Siden 2005 har Verdensdagen mer enn doblet budsj ettet, og de fleste fylkeslagene satser i 2008 på større arrangementer med tydeligere faglig forankring. LEV E har siden 2007 valgt å trykke opp en egen brosjyre til verdensdagen.

Å rets nasjonale arrangement vil finne sted i 0 slo i form av en fagkonferanse i $G$ amle Logen 10. september, kl. 9-16. Foredragsholdere vil bli Lars M ehlum, Berit G røholt, Ingeborg R ossow, Ildri Kjølseth og Pål K ristensen. Studenter og medlemmer av LEVE betaler ikke konferanseavgift.

LEV E har også fått midler fra H elsedirektoratet til å utvikle konseptet rundt en helaftens dokumentarfilm med selvmordsforebygging som tema. U tviklingsmidler til dette prosjektet er også gitt fra Scheiblers legat, og arbeidet vil trolig starte før sommeren. En dokumentarfilm vil føye nok et uttrykk til Verdensdagens nasjonale arrangementer og vil forhåpentligvis nå mange nye grupper.

For mer informasjon om aktiviteter lokalt, se www.leve.no under fylkesl agenes egne sider.

Det legges ned atskillige timer frivillig arbeid i Verdensdagen, og vi oppfordrer herved fagmiljøene til å støtte opp om Verdensdagen og aktivitetene i nærmiljøet i forbindel se med 10 . september.

\section{LEVE}

Landsforeningen for etterlatte ved selvmord

For mer informasjon om Verden sdagen for selvmordsforebygging, ta kontakt med prosjektleder G ry Lunde i LEV Es sekretariat på tlf. 22502570 / 41140559 eller e-post: post@leve.no / www.leve.no

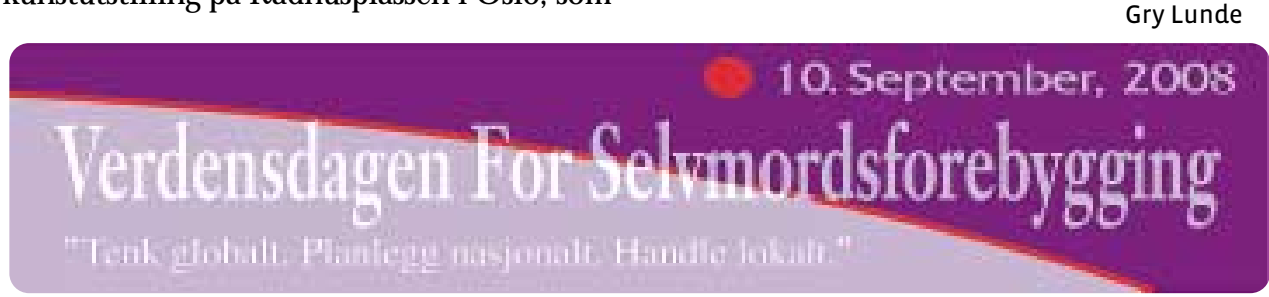

